The change in rhetoric is never ending. However, the process serves to remind that exorcising the specter of racial violence is a matter of redefining the larger issues of freedom and equality as well as obtaining effective enforcement of civil rights law.

\title{
THE NON-COMMUNIST AFFIDAVIT REQUIREMENT OF THE TAFT-HARTLEY ACT
}

Recent developments have brought into focus the basic conflict which exists between the peculiar mechanism chosen by Congress to rid unions of Communist officers and the broader objectives of the amended National Labor Relations Act. ${ }^{x}$ Section 9(h) of that Act $^{2}$ denies the use of National Labor Relations Board facilities to unions whose officers fail to file non-Communist affidavits. ${ }^{3}$ Fundamental to the Act's objective of industrial harmony is the establishment of orderly procedures for enforcing the obligations it imposes upon employers. ${ }^{4}$ In applying Section $9(\mathrm{~h})$, the Board and the courts often must choose between sacrificing the collective bargaining principle and strengthening the position of union officers who fail to comply with the filing requirements. ${ }^{5}$

${ }_{49}$ Stat. 449 (I935), as amended, 6I Stat. $x_{36}$ (r947), 29 U.S.C.A. \$ 4 I (Supp., I95o). In upholding the constitutionality of the provision, the Supreme Court declared that the purpose of Congress was to eliminate the "political" strike. "Substantial amounts of evidence were presented to various committees of Congress ... that Communist leaders of labor unions had in the past and would continue in the future to subordinate legitimate trade union objectives to obstructive strikes when dictated by Party leaders, often in support of the policies of a foreign government." American Communications Ass'n, CIO v. Douds, 339 U.S. 382,388 (I950).

= Labor Management Relations Act of $1947, \S 9(\mathrm{~h})$, 6I Stat. r46 (1947), 29 U.S.C.A. \& I59(h) (Supp., I950).

3 The Section is one of three which require unions to report various types of information. Sections $g(f)$ and $g(g)$ require financial and organizational reports of unions seeking the use of NLRB machinery. 6I Stat. $1_{45}, 1_{46}$ (I947), 29 U.S.C.A. $\$ \S 1_{59}(\mathrm{f}), \mathrm{r}_{59}(\mathrm{~g})$ (Supp., $\mathrm{x}_{950}$ ). While attention in this note has been focused upon the non-Communist affidavit, most of the disabilities that attach to noncompliance refer as well to these other filing requirements.

1 The declaration of policy, for example, states that "[i]t is the purpose and policy of this Act, in order to promote the full flow of commerce, to prescribe the legitimate rights of both employees and employers in their relations affecting commerce, to provide orderly and peaceful procedures for preventing the interference by either with the legitimate rights of the other. . . ." Labor Management Relations Act of 1947 , \& I (b), 6I Stat. $x_{3} 6$ (r947), 29 U.S.C.A. $\$ 15$ I(b) (Supp., $x_{950}$ ).

$s$ Opponents of the measure early pointed out the nature of the conflict involved. In his message to Congress vetoing the Act, President Truman stated: "Such a union would have to win all its objectives by strike rather than by orderly procedure under the law. The union and the affected industry would be disrupted for perhaps a long period of time while violent electioneering, charges and counter-charges split open the union ranks. ... This provision in the bill is an attempt to solve difficult problems of industrial democracy by recourse to over-simplified legal devices." NLRB, Legislative History of the Labor Management Relations Act 921 ( $x_{948} 8$ ). Senator Morse stated: "We do not help the patriotic membership of [noncomplying] unions by requiring them to strike in order to protect the economic rights and benefits which other workers enjoy." Ibid., at $x, 559$. See also the remarks of Senator Murray, ibid., at $x, 049$. 
Section $9(\mathrm{~h})$ provides that:

No investigation shall be made by the Board of any question ... concerning the representation of employees, raised by a labor organization, ... no petition [for a union shop] shall be entertained, and no complaint shall be issued pursuant to ... [an unfair labor practice] charge made by a labor organization ... unless there is on file with the Board ... [a non-Communist] affidavit executed contemporaneously or within the preceding twelve-month period by each officer of such labor organization and the officers of any national or international labor organization of which it is an affiliate or constituent unit....6

In the representation and union shop cases, the Board and the courts have had little difficulty in carrying out the intent behind the Section. In cases involving unfair labor practices, however, considerable difficulty has been encountered in attempting to resolve the conflict between the provision and the Act as a whole. It is relevant to examine the rules developed in these three types of cases to determine their limitations and practical impact.

\section{REPRESENTATION AND UNION SHOP CASES}

Where a noncomplying union not previously recognized by the employer or certified by the Board is unable to achieve recognition through its economic strength, Section $g(h)$ sometimes imposes serious disabilities. Such a union can neither petition for nor participate in an election ${ }^{7}$ and, since it cannot be certified, it will not have the protection which the Act grants to certified unions against striking rivals. ${ }^{8}$ The Board has prevented possible circumvention of the statute by adopting the so-called "fronting" rule. Under that rule, an individual ascertained to be acting in behalf of a noncomplying union will be denied a place on the ballot, ${ }^{9}$ despite the fact that the filing requirements do not ordinarily relate to individuals. ${ }^{10}$ So, too, a national complying union may not appear in behalf of its noncomplying local, ${ }^{\mathrm{rx}}$ even where the local does not participate in collective bargaining. ${ }^{x}$

Where the noncomplying union is the subject of a decertification proceed-

${ }^{6}$ Labor Management Relations Act of 1947 , $\$ 9(\mathrm{~h})$, 6x Stat. I46 (I947), 29 U.S.C.A. $\S$ I59(h) (Supp., I950).

${ }^{7}$ Sigmund Cohn Mfg. Co., 75 N.L.R.B. 377 (I947). The rule applies even where the employer requests an election. Herman Loewenstein, Inc., 75 N.L.R.B. 377 (I947). Ordinarily, the employer may petition for an election when presented with claims from rival unions. Labor Management Relations Act of I947, $\$ 9$ (C)(I)(B), 6I Stat. I44 (x947), 29 U.S.C.A. $\S I 59(\mathrm{c})(\mathrm{I})(\mathrm{B})$ (Supp., I950).

${ }^{8}$ Labor Management Relations Act of $\mathrm{x}_{947}$, $\S 8(\mathrm{~b})(4)(\mathrm{C})$, 6r Stat. $x_{4} \mathrm{x}$ (r947), 29 U.S.C.A. $\S I_{5} 8(\mathrm{~b})(4)(\mathrm{C})$ (Supp., I950).

9 Oppenheim Collins \& Co., 79 N.L.R.B. 435 (1948); Campbell Soup Co., 76 N.L.R.B. 950 (I948).

ro Hofman Packing Co., 87 N.L.R.B. 60r (r949); Acme Boot Mfg. Co., 76 N.L.R.B. 44I (rg48).

Ir United States Gypsum Co., 77 N.L.R.B. rog8 (I948). Earlier, the Board had held the local's compliance status immaterial. Lion Oil Co., 76 N.L.R.B. 565 (I948); Warshawsky \& Co., 75 N.L.R.B. I29I (1948).

${ }^{x 2}$ Prudential Ins. Co. of America, 8I N.L.R.B. 295 (x949). 
ing, ${ }^{x_{3}}$ however, it will appear on the ballot. ${ }^{14}$ "To hold otherwise," said the Board, "would confer upon noncomplying unions the power to immunize themselves against decertification proceedings by their very refusal to comply...." Is If the noncomplying union wins, the Board will not certify the union, but only the arithmetic results of the election..$^{16}$

The Board is forbidden by Section $9(\mathrm{~h})$ to entertain a union shop petition presented by a noncomplying union. Unless the Board has certified that a majority of the employees authorized a union shop agreement, it would be an unfair labor practice for a union to force an employer to carry out such an agreement. ${ }^{17}$ It is thus clear that a noncomplying union cannot lawfully attain a union shop either through NLRB facilities ${ }^{18}$ or through its own economic strength. ${ }^{19}$.

\section{Unfair Labor Practices: Duty to Bargain Cases}

Under Section 8(a)(5) of the $\mathrm{Act}^{20}$ an employer is guilty of an unfair labor practice if he refuses to bargain with the representative of the majority of his employees. Whether an employer is relieved of the duty to bargain with a majority union which has not complied with Section $9(\mathrm{~h})$ becomes important where a complying union brings charges based upon a refusal to bargain which occurred while it was not in compliance. ${ }^{2 x}$ Although a majority union could normally, upon compliance, force the employer to bargain through a new demand for recognition, it might have lost its majority status before complying. Where the union is initially insecure in its hold on the membership, the absence of a duty to bargain could lead to this result. On the other hand, a holding

${ }_{13}$ Decertification applies to a union either certified by the Board or currently recognized by the employer. Labor Management Relations Act of $1947, \S 9$ (c)(I)(A)(ii), 6r Stat. $x 44$ (I947), 29 U.S.C.A. $\S I_{59}$ (c) (I)(A)(ii) (Supp., I950).

${ }^{2} 4$ Harris Foundry \& Machine Co., 76 N.L.R.B. II8 (I948).

35 Ibid., at 120 .

${ }^{36}$ Stauffer Chemical Co. of Texas, 85 N.L.R.B. 595 (x949).

${ }^{17}$ Section 8(b)(2) makes it an unfair labor practice for a union to force an employer to discriminate against an employee for non-membership in the union. 6I Stat. I4I (I947), 29 U.S.C.A. $\$ 15^{8(b)(2) ~(S u p p ., ~ I 950) . ~ S e c t i o n ~ 8(a) ~(3) ~ m a k e s ~ i t ~ a n ~ u n f a i r ~ l a b o r ~ p r a c t i c e ~ f o r ~ a n ~}$ employer to carry out a union shop agreement unless the Board has certified that a majority of the employees authorized the agreement. 6I Stat. I40 (r947), 29 U.S.C.A. \& $158(a)(3)$ (Supp., r950).

${ }^{8}$ H. C. Godman Co., 79 N.L.R.B. I30 (I948).

x9 Cf. Simons v. Retail Clerks Union, 2I L.R.R.M. 2685 (Cal. Super. Ct., x948). In Julius Resnick, Inc., 86 N.L.R.B. 38 (r949), where a union security provision was illegally inserted into a contract, the employer was ordered to withhold recognition until the union had been certified by the Board. See also Hager \& Sons Hinge Mfg. Co., 8o N.L.R.B. I63 (I948). The Board, of course, will not certify a noncomplying union and it appears that no agency other than the NLRB can conduct a valid union shop election. NLRB Release R-48 (Mar. 1o, x948).

${ }^{20} 6$ I Stat. I4I (1947), 29 U.S.C.A. \& x58(a)(5) (Supp., r950).

${ }^{2 x}$ No complaint can issue, however, based upon a practice occurring more than six months prior to the filing of the charge. Labor Management Relations Act of $x 947, \S$ Io(b), 6r Stat. I46 (r947), 29 U.S.C.A. § I60(b) (Supp., I950). 
that the employer was under a duty to bargain despite the union's noncompliance would probably result in an order to bargain irrespective of the union's loss of membership, such loss being attributed to the commission of the unfair labor practice. ${ }^{22}$ Strikers would have to be reinstated ${ }^{23}$ and, if necessary, workers hired to replace them would have to be discharged..$^{24}$

In Andrews $C_{0.25}$ the Board held that in such a case the employer is under no duty to bargain ${ }^{26}$ even where the union's noncompliance was not a factor influencing his behavior. Since the statute creates both the right and the remedy, the Board reasoned, "a limitation on the remedy is to be treated as a limitation on the right itself." ${ }_{27}$ Furthermore, a contrary holding would permit the circumvention of the Section, since a noncomplying union "could compel recognition by the mere threat of subsequent compliance and the filing of a charge." ${ }_{28}$

The Board's holding in the Andrezes case was rejected by the Court of Appeals for the District of Columbia in West Texas Utilities v. NLRB.29 The court argued that the obligation to bargain imposed by Section $8(\mathrm{a})(5)$ is unqualified unless something in Section $9(\mathrm{~h})$ relieves the employer of that obligation where union officers fail to comply. It found that nothing in the latter section so limited the employer's duty since "[t]he Act's only sanction for noncompliance

${ }_{22}$ NLRB v. Bradford Dyeing Ass'n, 3 Io U.S. 3 I8 (r940); Craddock-Terry Shoe Corp., 73 N.L.R.B. 1339 ( 1947$)$.

${ }^{23}$ Harris-Woodson Co., 77 N.L.R.B. 819 (1948). The Board is empowered, with respect to unfair labor practices, "to take such affirmative action including reinstatement of employees with or without back pay, as will effectuate the policies of this Act." Labor Management Relations Act of I947, 6r Stat. ${ }_{47}$ (I947), 29 U.S.C.A. \$ 160(c) (Supp., I950).

${ }_{24}$ E.g., Harris-Woodson Co., 77 N.L.R.B. 8r9 (I948).

2587 N.L.R.B. 379 (r949).

${ }^{26}$ The Board believed that the result reached was required by its prior decision in Marshall and Bruce Co., 75 N.L.R.B. 90 (I947). In that case, the complaint had issued and the case was pending determination at the time the Act went into effect. The Board found that the employer had violated the duty to bargain, and also that it had the power to issue a remedial order despite the union's noncompliance. However, on the issue of how that power was to be exercised, the Board held that an unconditional order would be tantamount to certification of the union. Since they could not "believe that Congress intended the full force of Government to be brought to bear upon an employer to require him to bargain in the future with a Union which we now lack authority to certify," the order to bargain was conditioned on the union's compliance within thirty days. Ibid., at 96 . If, after the Board's order, the union again demanded recognition, subsequently complied and brought charges, a situation like that in the Andrews case would be presented. Holding that the employer should have bargained with the union while it was not in compliance would be an anomalous result, particularly if the union's request for recognition, but not its compliance, had occurred less than thirty days after the Board's order. A result similar to the Marshall and Bruce Decision was reached in Inland Steel Co., 77 N.L.R.B. I (1948), aff'd Inland Steel Co. v. NLRB, 170 F. 2d 247 (C.A. 7 th, I948), aff'd sub nom. American Communications Ass'n, CIO v. Douds, 339 U.S. $3^{82}$ (1950) on the issue of the constitutionality of Section $9(\mathrm{~h})$.

${ }^{27}$ Andrews Co., 87 N.L.R.B. 379, 382 (I949).

${ }^{28}$ Ibid.

${ }_{29}$ I84 F. 2d 233 (App. D.C., 1950). 
is denial of Board facilities." 30 Moreover, the court thought that limiting the obligation would be inconsistent with the statutory language. The Board is forbidden to issue a complaint on behalf of a union unless it has on file affidavits executed "contemporaneously or within the preceding twelve-month period." ${ }^{3 x}$ Therefore, it reasoned, the statute contemplated that the unfair labor practice which was the subject of the complaint might have arisen before the union had complied. ${ }^{2}$

Recently, in New Jersey Carpet Mills, Inc., ${ }^{33}$ the Board has followed the West Texas decision ${ }^{34}$ and has overruled its own holding in the Andrews case. Here, as in Andrews Co., the employer did not rely upon the union's noncompliance as a justification for his refusal to bargain. The Board, in a three-to-two decision, held that the employer's refusal to bargain constituted an 8(a)(5) violation. One of the majority, Chairman Herzog, suggested that the employer should not be found guilty of an unfair labor practice where he contemporaneously notifies the union that its noncompliance is the basis for his refusal to bargain. In such circumstances, "realism should oblige the Board to recognize not only that the employer's position may well be consistent with a good-faith recognition of the basic principle of collective bargaining, but that its very assertion will tend to encourage early union compliance...." ${ }_{35}$ In a special concurring opinion, the other two members of the majority declined to take a

30 Ibid., at 239 .

${ }^{3 x}$ Labor Management Relations Act of 1947 , $\$ 9(\mathrm{~h})$, 6r Stat. ${ }_{4} 6$ (I947), 29 U.S.C.A. \& I59(h) (Supp., I950).

32 While the court appears to have relied heavily on the use of the word "contemporaneously," the argument would be precisely the same were the court to rely only on the words "within the preceding twelve-month period."

${ }_{33} 2$ CCH Lab. L. Rep. I ro,50I, 92 N.L.R.B. No. I22 (I950).

34 The Board might have treated the decision of the West Texas case on this point as dictum. The union in that case had been in compliance at all times, but its parent federation had not. The court agreed with the Board's holding in Northern Virginia Broadcasters, Inc., 75 N.L.R.B. II (1947) (in which the Board rejected a prior opinion of its own General Counsel) and held that the federations ordinarily were not "labor organizations" within the meaning of the Act. "Even if it were true that federation officers were required to file and had failed to do so," the court then went on to argue, "the failure ... does not in any way relieve an employer of the paramount obligation to bargain collectively in good faith." West Texas Utilities v. NLRB, 184 F. 2d 233, 239 (App. D.C., 1950). On the issue of whether or not the AFL and CIO must comply with the requirements of Section $g(\mathrm{~h})$, the West Texas decision has in effect been overruled by the Supreme Court's recent decision in NLRB v. Highland Park Mfg. Co., B.N.A. Daily Labor Report No. 94, at D-I (r95r). The West Texas case is being appealed. 6 CCH Lab. L. Rep. 90,00x (r95I).

35 B.N.A. Daily Labor Report No. 24I, at E-7 (r950). This situation actually arose in Hoover Co. v. United Electrical Workers, $x_{5} \mathrm{CCH}$ Lab. Cas. $\pi 64,6 \mathrm{r}_{3}$ (Ohio C.P., x948). The company based its refusal to negotiate a contract on the union's noncompliance, but the court held that such a refusal violated the spirit of the Taft-Hartley Act and ordered the employer to bargain. Similar situations were also presented in United Electrical Workers v. Lilienthal, 84 F. Supp. 640 (D.C., I949) and in Remington Rand, Inc., 78 N,L,R.B. I8I (I948), but the cases were disposed of on other grounds. 
stand on the hypothetical situation envisaged by Chairman Herzog. ${ }^{36}$ Regardless of their position in such a case, however, unless the Board is reconstructed it is probable that Herzog's rule will be decisive. ${ }^{37}$

The Herzog rule, like the "substantive" interpretation of Section $9(\mathrm{~h})$ developed in the Andrewes case, finds little justification in the language of the Section. The "procedural" rule of the West Texas case seems consistent with that language, although the court's interpretation is not free from doubt. It could be argued that the reference to affidavits filed within the preceding twelve-month period was designed to protect only those unions whose compliance had lapsed after a demand for recognition had been refused while the union was in compliance..$^{8}$ On the other hand, it has been argued that the legislative history of Section 8(a)(5) supports the West Texas interpretation. The House bill would have amended Section 8(5) of the Wagner Act ${ }^{39}$ by limiting the employer's obligation to bargain to situations in which a union was already recognized or certified. $4^{\circ}$ Congress' rejection of this proposal has been taken as evidence of an intent to leave unqualified the employer's obligation to bargain with a majority union. $4^{\mathrm{x}}$ But this legislative history is not necessarily persuasive. The rejection of the House proposal can be explained on the ground that Congress was unwilling to make a general change in the employer's duty to bargain and that its failure to enact this proposal is neutral as an indication of congressional intent regarding the specific and narrow problem of the duty to bargain with a noncomplying union.

While the "substantive" rule attempts to solve the conflict between the intent behind Section $9(\mathrm{~h})$ and the over-all objectives of the Act by giving effect

${ }^{36}$ B.N.A. Daily Labor Report No. 24I, at E-ro (I950).

37 It may be, however, that Chairman Herzog would not apply his rule in every case where the employer relies on the union's noncompliance. Parts of his opinion indicate that the rule is based upon an unwillingness to let an employer who shows contempt for the collective bargaining principle avail himself of a "windfall" in a later discovery of the union's noncompliance. Because of such behavior on the part of the employer, the assertion of the union's noncompliance would not be consistent with a good faith recognition of the basic principle of collective bargaining. Surely, as to that employer, the union's noncompliance would be no less a windfall if discovered sooner, rather than later. Indeed, in Tennessee Egg Co., 27 L.R.R.M. I479, I48I n. I3, 93 N.L.R.B. No. I4I (I95I), Chairman Herzog found "no merit in the Respondent's contention that this case falls within the principle he espoused in theNew Jersey Carpet case. The respondent herein did not contemporaneously notify the Union that the latter [sic] noncompliance was the reason for its refusal to bargain, nor indeed is there any proof that it was notivated thereby" (emphasis added).

${ }^{38}$ The House Bill would have denied certification to a union any of whose officers were members of the Communist Party. H.R. 3020, 8oth Cong. Ist Sess. (I947), at $\S 9(f)(6)$. In order to relieve the Board of the task of determining whether union officers were Communists, the affidavit provision and the present language of Section $g(h)$ were substituted for the House proposal in the conference agreement. Consult remarks of Senator Taft, NLRB, op. cit. supra note 5 , at $I, 542$. It could thus be argued that the particular language employed is necessary only because of the affidavit device and that there was no intent to make the Section apply retroactively in behalf of unions which complied after the unfair labor practice was committed.

3949 Stat. 453 (I935).

${ }^{40}$ H.R. 3020, 8oth Cong. Ist Sess. (x947), at $\$ 8(a)(5)$.

${ }^{4 I}$ New Jersey Carpet Mills, Inc., B.N.A. Daily Labor Report No. 24I, at E-6 (I950). 
in all cases to the former, the "procedural" rule recognizes the latter as paramount. The Herzog rule is an attempt to compromise between these extremes. Under that rule, no important sacrifice of the Act's broader objectives need be made, since the intent behind Section 9 (h) will be effectuated only where the employer's conduct is consistent with his acceptance of the collective bargaining principle. A further advantage of the rule is that it would encourage disclosure to a possibly misinformed membership of the reason for the employer's refusal to negotiate and thereby weaken the position of noncomplying officials.

\section{Other Unfair Labor Practice Cases}

The choice between effectuating the intent behind Section $g(\mathrm{~h})$ and other objectives of the Act in cases arising under the first four subsections of Section 8(a) has been made without the difficulties which were anticipated. ${ }^{2}$ These . subsections are designed to protect employees in their organizational activities; 43 to prevent domination of the union by the employer; 44 to prevent discrimination against union members; 45 and to protect employees giving testimony under the Act. ${ }^{6}$ Section $g(h)$ precludes a noncomplying union from bringing charges based on these subsections.

Nevertheless, the rulings in these cases greatly reduce the disabilities of noncompliance. The Board early distinguished between these charges and Section 8(a)(5) charges so far as Section 9 (h) was concerned.47 The Andrews case itself held that a complying union could bring other than Section 8(a) (5) charges against the employer for acts committed prior to compliance. $4^{8}$ Since such acts injured individual employees, the Board held that the noncompliance of the union could not be raised as a defense by the employer. In $N L R B$ v. Augusta Chemical Co. ${ }^{49}$ charges previously dismissed because of the noncompliance of the complaining union were brought by individual members of the union. The employer's contention that the "fronting" rule should apply was rejected even though it was known that the union was actually preparing the case. The Board has even allowed charges to be brought by officers ${ }^{50}$ and attorneys ${ }^{5 x}$ of noncomplying unions..$^{52}$

\footnotetext{
4 Consult Kearns, Non-Communist Affidavits Under the Taft-Hartley Act, 37 Geo. L.J. 297 (1949).

436 I Stat. 140 (1947), 29 U.S.C,A. \& I58(a)(I) (Supp., I950).

44 6r Stat. I40 (I947), 29 U.S.C.A. \& I58(a)(2) (Supp., I950).

456 I Stat. 140 (1947), 29 U.S.C.A. $\$$ I58(a)(3) (Supp., 1950).

${ }^{6} 6$ r Stat. I4I (I947), 29 U.S.C.A. $\$$ r $_{5} 8$ (a) (4) (Supp., I950).

${ }_{47}$ Pioneer Electric Co., 75 N.L.R.B. II7 (I947); Marshall and Bruce Co., 75 N.L.R.B. 90 (1947).

$4^{8}$ Andrews Co., 87 N.L.R.B. 379 (I949).

496 CCH Lab. L. Rep. I 66,177 (C.A. 5th, I95 I), enforcing 83 N.L.R.B. 53 (I949).

so Luzerne Hide \& Tallow Co., CCH Lab. L. Rep. If 9997, 89 N.L.R.B. No. II9 (I950).

5x Olin Industries, Inc., 86 N.I.R.B. 203 (I949).

${ }^{2}$ In these cases the Board relied on Section ro(b) of the Act, under which unfair labor practice charges may be brought by anyone. 6r Stat. 146 (1947), 29 U.S.C.A. \& 160(b) (Supp., I950). It is almost certain, however, that the Board would not go so far as to act on an 8(a)(5)
} 
It is questionable whether sufficient attention has been given to the problem inherent in these cases. True, a rule which prevents a noncomplying union from filing unfair labor practice charges imposes some disability in that it may affect the union's prestige and provide propaganda for rival organizations. But it is significant that so long as an individual may file such charges in behalf of a noncomplying union, the union's organizational activities can effectively be protected from antagonistic employers. It would seem that the intent behind Section $9(\mathrm{~h})$ would best be effectuated in these cases by application of the "fronting" rule where it is clear that the primary benefit of the Board's order would accrue to a noncomplying union.

\section{Limitations of Section 9 (H)}

The disabilities imposed by Section 9 (h) have helped to bring about the compliance of a substantial majority of unions subject to the Act. ${ }^{53}$ It is not clear, however, that the provision has had a decisive effect in eliminating Communist officers from the labor movement. Many unions never had such officers. Others have rid their ranks of Communists on their own initiative as a result of the same forces which led to the passage of Section $9(\mathrm{~h})$ and which have since been accentuated by the Korean war. 54

Many unions have achieved technical compliance without yielding to the spirit of the Section. Where officers would not, or could not file affidavits, they have often been cloaked with lesser titles so as not to be included in the list of "officers" submitted by the union. ${ }^{55}$ Although the Board's rules have been amended in an attempt to eliminate this practice, ${ }^{66}$ it may be possible to achieve

violation brought by an individual where a noncomplying union is involved. If it did, its order in such a case would require the employer to bargain. But it was held in Marshall and Bruce Co., 75 N.L.R.B. 9o (r947), that an order to bargain was tantamount to certification, a step which the Board is forbidden to take in behalf of a noncomplying union. See also Luzerne Hide \& Tallow Co., CCH Lab. L. Rep. I 9997, 89 N.L.R.B. No. rI9 (r950), where the Board distinguishes between $8(a)(5)$ and other charges when brought by individuals.

s3 "Today the United Mine Workers stands in lonely magnificance [sic] as the sole major unit outside the $9(\mathrm{~h})$ fold." Shair, How Effective is the Non-Communist Affidavit?, I CCH Lab. L.J. 935, 940 ( 1950 ). On June 30, 1950,213 national and international unions were in compliance. Of the 22,697 local unions which had complied at one time or another, however, I $x, 353$ had permitted their filing of affidavits to lapse. NLRB, Fifteenth Annual Report I8 (I950). This may merely reflect the fact that contracts are being entered into for greater periods of time. Perhaps it also reflects the fact that employers generally have not seized the opportunity to refuse to negotiate with noncomplying unions. Consult Kearns, op. cit. supra note $4 \mathrm{r}$.

54 The action of the CIO, for example, in revoking the charters of several allegedly Communist-dominated unions was undertaken regardless of the fact that those unions had complied with Section $9(\mathrm{~h})$. Consult Levinson, Left-Wing Labor and the Taft-Hartley Law, I CCH Lab. L.J. Io79, rogo (I950).

55 The Board at first considered itself helpless against this method of evasion. CraddockTerry Shoe Corp., 76 N.L.R.B. 842 (I948).

${ }^{56}$ The Board may now require affidavits from individuals it suspects are carrying on "officer" responsibilities. 29 Code Fed. Regs. \& ro2.13 (c) (Cum. Supp., I949). However, unless there are grounds for suspicion, the list of offcers submitted by the union will usually be accepted as complete for the purposes of determining compliance. NLRB, Fifteenth Annual Report 20 (r950). 
compliance by having such officers "resign" their positions until Board facilities have been successfully invoked.

Even those unions whose officers hold questionable political views will achieve compliance upon submission of affidavits completed by such officers, since the genuineness of affidavits will be considered only in a criminal prosecution by the Department of Justice.57 Perhaps in an effort to assure continued Board recognition of their union and to avoid the risk of personal criminal liability, some union officers who were well-known Communists publicly announced their "resignations" from the Party and disavowed any belief in the forceful overthrow of the government..$^{8}$ Because of the multifarious means of frustrating the purposes of Section $9(\mathrm{~h})$, a recent congressional report criticizes the provision as creating "a false illusion of security" with respect to the prevalence of Communists in labor unions. 59

Without resorting to methods of circumvention, many unions have been practically immune from the pressures exerted by Section 9 (b). Except where some other union has been certified, ${ }^{60}$ nothing in the Act prevents an employer from granting recognition to a majority union, either peaceably ${ }^{6 x}$ or as a result of a strike. ${ }^{62}$ Board certification of majority status-and hence, compliance-is not necessary where the union can establish its majority through authorization or membership cards. ${ }^{63}$ While the employer may challenge the sufficiency of such proof and insist upon a Board election, ${ }^{64}$ the challenge must proceed from

57 Chesapeake and Potomac Telephone Co. of Va., 82 N.L.R.B. 8 ro (I949) (genuineness of affidavits not a litigable issue before the Board). The Board sends those it suspects of being false to the Department of Justice. NLRB Release R-202 (June ${ }_{4}, x_{949}$ ). To date, however, no prosecutions seem to have occurred. Shair, op. cit. supra note 53 , at 942 .

${ }^{8}$ Shair, op. cit. supra note 53 , at 940 .

s9 Sen. Rep. No. 99, Part I (Majority Report), 8Ist Cong. Ist Sess. 5 I (I949).

${ }^{\circ}$ Section $8(\mathrm{~b})(4)$ (C) of the Act prohibits strikes for the purpose of obtaining recognition where the certification of another is in effect. 6I Stat. I 4 I (I947), 29 U.S.C.A. \& I58(b)(4)(C) (Supp., 1950). But in Douds v. Local 1250 , I 73 F. 2d 764 (C.A. 2d, I949), it was held that this section does not forbid a strike to force recognition for the purpose of "adjusting" any dispute not provided for in an existing collective bargaining agreement even where another representative has been certified. The court's language indicates that in such circumstances the employer and an uncertified noncomplying union can bargain with respect even to matters which heretofore were within the exclusive jurisdiction of the certified representative. Consult Collective Bargaining, Grievance Adjustment and the Rival Union, I7 Univ. Chi. L. Rev. 533 (I950).

6x Consult letter, Jan. 23, I948, by Labor Solicitor Tyson to Secretary of Labor Schwellenbach reprinted $2 \times$ L.R.R.M. 62.

${ }^{62}$ Some state courts have taken a contrary position. In Scranton Broadcasters, Inc. v. American Communications Ass'n, $1_{3}$ CCH Lab. Cas. \#64, I 24 (Pa. C.P., I947), a noncomplying union's strike for recognition was enjoined; and in Fulford v. Smith Cabinet Mfg. Co., XI8 Ind. App. 326, 77 N.E. 2d 755 (I948), the union's noncompliance was held to forfeit the protection which otherwise would have been afforded by the state anti-injunction law. It is also interesting to note that the absence of a non-Communist provision in a state labor statute was held to be so inconsistent with the N.L.R.A. as to prevent the NLRB from ceding jurisdiction over a case to the state agency. Kaiser-Frazer Parts Corp., 80 N.L.R.B. I050 (I948).

$6_{3}$ Harris-Woodson Co., 77 N.L.R.B. 819 (r948).

${ }^{64}$ Georgia Twine \& Cordage Co., 76 N.I.R.B. 84 (r948). 
a bona fide doubt as to the union's majority. ${ }^{65}$ Furthermore, where the union's majority status has been certified by the Board within the prior year, it cannot be challenged by the employer, regardless of the union's present noncompliance. ${ }^{66}$ Even after expiration of the year, a presumption of continuing majority status exists. ${ }^{67}$ Where an election is held without the participation of the noncomplying union, the ability to prevent rival organizations from obtaining a majority in that contest ${ }^{68}$ will protect the union against certification of others for at least a year. ${ }^{69}$ In a like manner, certification of rivals can be prevented where the noncomplying union has a current contract with the employer..$^{\circ}$

Because of these circumstances, it would appear that the Section is least effective where more powerful unions are involved. This seems anomalous since Congress was presumably most concerned over the threat to commerce and national security inherent in the Communist domination of such unions. ${ }^{7 x}$ In this respect it is significant that the rules worked out in the unfair labor practice cases help prevent loss of strength. On the other hand, such unions, because of their inability to appear on the ballot or achieve a union shop, have suffered losses through the "raiding" tactics of rival complying organizations.72 But even if the union is so weakened that it lacks the economic power to strike for recognition, so long as it maintains a majority the demise of the Andrews rule may discourage the employer from refusing to bargain.

\section{THE INTERNATIONAL SHOE DOCTRINE AND JURIS- DICTION ON THE BASIS OF ACTS}

Johns v. Bay State Abrasive Products $C_{0} .^{\mathrm{I}}$ is the first case interpreting and testing the validity of a Maryland statute extending the area of state jurisdiction over foreign corporations. Section $\operatorname{IIg}(\mathrm{d})$ of that statute provides that

${ }^{65}$ John Deere Plow Co. of St. Louis, 82 N.L.R.B. 69 (r949); D. H. Holmes Co., 8r N.L.R.B. 753 (r949). "Whether in a particular case an employer is acting in good or bad faith, is of course a question which of necessity must be determined in the light of all the relevant facts in the case. Among the factors pertinent to a determination of the employer's motive at the time of the refusal to bargain are any unlawful conduct of the employer, the sequence of events, and the lapse of time between the refusal and the unlawful conduct." Artcraft Hosiery Co., 78 N.L.R.B. 333,334 (I948).

${ }^{66}$ Shawnee Milling Co., 82 N.L.R.B. 1266 (r949).

${ }^{6} 7$ Dorsey Trailers, Inc., 80 N.L.R.B. $47^{8}$ (I948).

${ }^{68}$ The noncomplying union is permitted to campaign against its rival. Woodmark Industries, Inc., 80 N.L.R.B. Iro5 (r948).

${ }^{69}$ No election can be held within one year after a valid election has been conducted. Labor

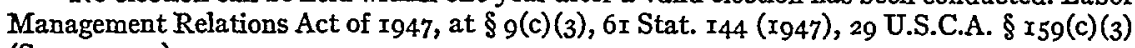
(Supp., r950).

${ }^{20}$ Aluminum Co. of America, 85 N.L.R.B. 9 I 5 (I949). In the absence of a contract, however, the noncomplying union has not even the standing to file objections to the conduct of the election. Times Square Stores Corp., 79 N.L.R.B. 361 (I948).

${ }^{7 x}$ See, e.g., the remarks of Representative Hartley, NLRB, op. cit. supra note 5 at 6 r3.

72 Consult Levinson, op. cit. supra note 54 at ro87 et seq.

$\times 8$ F. Supp. 654 (D.C. Md., I950). 